\title{
Lipid biomarkers and trophic linkages between ctenophores and copepods in Svalbard waters
}

\author{
Stig Falk-Petersen ${ }^{1, *}$, Trine M. Dahl ${ }^{1}$, Catherine L. Scott ${ }^{2}$, John R. Sargent ${ }^{2}$, \\ Bjørn Gulliksen ${ }^{3}$, Slawomir Kwasniewski ${ }^{4}$, Haakon Hop ${ }^{1}$, Rose-Mary Millar ${ }^{2}$ \\ ${ }^{1}$ Norwegian Polar Institute, 9226 Tromsø, Norway \\ ${ }^{2}$ Institute of Aquaculture, University of Stirling, Stirling FK9 4LA, Scotland, UK \\ ${ }^{3}$ The University Courses on Svalbard, UNIS, Post Box 156, 9170 Longyearbyen, Svalbard, Norway \\ ${ }^{4}$ Institute of Oceanology, Polish Academy of Sciences, Powstancow Warszawy St 55, 81-712 Sopot, Poland
}

\begin{abstract}
The lipid class compositions of the ctenophores Mertensia ovum and Beröe cucumis were very similar, with polar lipid and wax esters each accounting for 35 to $40 \%$ of the total. The fatty acid compositions of the polar lipids in the 2 species were essentially the same, with $22: 6 \mathrm{n} 3$ and $20: 5 \mathrm{n} 3$ in a ratio of $2: 1$ accounting for more than $40 \%$ of the total. The fatty acid and fatty alcohol compositions of the wax esters of both species were also essentially the same, with 20:1n9 and 22:1n11 fatty alcohols present in equal amounts accounting for $60 \%$ of the total fatty alcohol composition. The fatty acid and fatty alcohol compositions of the wax esters of $M$. ovum and B. cucumis were averaged and compared, using principal component analyses, to averages derived from published data for the potential prey species: Calanus finmarchicus, C. glacialis, C. hyperboreus, Pseudocalanus acuspes, Acartia longiremis and Metridia longa. The results were consistent with Calanus spp., especially $C$. glacialis, being the major prey of $M$. ovum and with $M$. ovum being the major prey of $B$. cucumis.
\end{abstract}

KEY WORDS: Lipids · Fatty acid profiles · Mertensia ovum $\cdot$ Beröe cucumis $\cdot$ Arctic

\section{INTRODUCTION}

The ctenophores Beröe cucumis and Mertensia ovum are significant predators of other zooplankton species in pelagic food chains. B. cucumis actively seeks prey by a specialised swimming behaviour (Tamm \& Tamm 1991) and M. ovum uses its extensive tentacles to entrap and ingest prey. It is well known that species of the genus Beröe feed primarily on other ctenophores and the food chain: copepods $-M$. ovum or the smaller ctenophore Bolinopsis infundibilum - $B$. cucumis, is a central feature in Arctic Seas (Zelikman 1972, Swanberg 1974, Harbison et al. 1978, Siferd \& Conover 1992, Falkenhaug 1996). These studies also showed that the distribution and abundance of $M$. ovum and $B$. cucumis were inversely related and it was suggested that $M$. ovum is the principle prey of $B$.

\footnotetext{
*E-mail: stig.falk-petersen@npolar.no
}

cucumis or, more correctly, that B. cucumis feeds on and controls the population of $M$. ovum. Both field studies (Siferd \& Conover 1992) and experimental studies (Swanberg \& Båmstedt 1991) have demonstrated an opportunistic feeding behaviour of $M$. ovum. These studies have also shown that the preferred or main prey of M. ovum comprises small (Pseudocalanus acuspes) to large copepods (C. finmarchicus, C. glacialis, C. hyperboreus and Metridia longa). As opposed to $M$. ovum, B. cucumis probably cannot digest crustaceans and, therefore, rely mostly on other gelatinous plankton (Kamishlov 1960, Hoeger \& Mommsen 1984, Falkenhaug 1996). The balance between copepod species, $M$. ovum (or B. infundibilum) and B. cucumis may have far reaching implications for production at other trophic levels. This applies particularly to high-latitude ecosystems where these ctenophores can be abundant, albeit variably, during late summer and autumn. Cod has been reported to feed on ctenophores in Arctic waters (Boldovsky 1944, 
Hansen 1949) and may thus be a significant predator on both M. ovum and B. cucumis in the study area. On the other hand, it has been demonstrated that $B$. infundibilum prey on fish larva (Kamishlov et al. 1958), which one also might suggest can be the case for M. ovum.

Lipid biomarkers can be used to trace energy and food transfers in marine ecosystems. Such use is based on studies of the lipid class and fatty acid and fatty alcohol compositional profiles of numerous algal and animal species (Sargent \& Whittle 1981), and on the knowledge of the transfer of fatty acids through the food chain from algae to top predators (Falk-Petersen et al. 1990, 2000a). More recently, fatty acid profiles have been combined with multivariate statistical techniques to investigate the foraging ecology of marine mammals (Iverson 1997a,b, Grahl-Nielsen \& Mjaavatten 1991, 1995, Smith et al. 1997, Brown et al. 1999, Dahl et al. 2000, Kirsch et al. 2000, Walton et al. 2000), birds (Raclot et al. 1998) and fish (Kirsch et al. 1998). In the present study, we used principal component analysis (PCA) to assist in the interpretation of synthesised fatty acid and fatty alcohol analytical data from Beröe cucumis, Mertensia ovum and copepods in order to illuminate trophic relationships between these species in Svalbard waters.

We were motivated to undertake this study because information on the feeding ecology of ctenophores in this area is rare. In addition, most previous dietary studies of these ctenophores elsewhere are based on stomach content analysis, which can give biased information due to differences in digestion rates of different prey and to the fact that the information is often extrapolated from a single meal only. By studying the transfer of lipid molecules, we intend to shed light on the important key species in the transfer of energy from phytoplankton to ctenophores. Only one lipid analytical study has previously been conducted on ctenophores (Clarke et al. 1987), but this study involved the Calanus-Bolinopsis-Beröe food chain and the study concluded that simple statistical analyses of fatty acid and fatty alcohol spectra were of limited value in establishing trophic relationships in pelagic food webs. We will therefore employ advanced multivariate statistics to further improve the methodology that can give us additional knowledge concerning the trophic significance of high Arctic ctenophores.

\section{MATERIALS AND METHODS}

The present study was carried out as part of the research programme 'Temporal and spatial variability of the Ice-Ocean system of the ice-edge in the marginal ice zone of the Barents Sea', which is a continua- tion of the ICE-BAR programme (Falk-Petersen et al. 2000b), and the 'BIODAFF Programme' in Kongsfjorden. Both programmes have been headed by the Norwegian Polar Institute.

Sampling. Sampling was carried out in Kongsfjorden, Svalbard ( $\left.78^{\circ} 57^{\prime} \mathrm{N}, 11^{\circ} 50^{\prime} \mathrm{E}\right)$, from 24 August to 22 September 1997. Mertensia ovum and Beröe cucumis were sampled individually from the surface in small beakers, from a small outboard-powered boat. Despite substantial efforts with zooplankton nets and SCUBA diving, individuals of $B$. infundibilum were not recorded. Individual animals were kept alive in seawater before being transferred into chloroform/ methanol $(2: 1, \mathrm{v} / \mathrm{v})$ within a few hours of capture at the laboratory in Ny-Ålesund. Samples in chloroform/ methanol were stored at $-20^{\circ} \mathrm{C}$ until analysed.

Lipid analyses. Total lipid was extracted from the samples stored in chloroform/methanol $(2: 1, \mathrm{v} / \mathrm{v})$ by the method of Folch et al. (1957), dried under nitrogen and then under vacuum for $24 \mathrm{~h}$, and weighed. The class composition of the total lipid content was measured by quantitative thin-layer-chromatography (TLC) densitometry as described by Olsen \& Henderson (1989). Lipids were eluted from chromatography plates with diethyl ether/hexane $(1: 1, \mathrm{v} / \mathrm{v})$. Triacylglycerols (TAG) and wax esters (WE) were separated on TLC silica gel plates using hexane/diethyl ether/acetic acid (90:10:1, v/v/v). The resultant lipid classes, as well as total lipid from each sample, were supplemented with a known amount of the fatty acid 21:0 as the internal standard, and transmethylated in methanol containing $1 \%$ sulphuric acid with toluene for $16 \mathrm{~h}$ at $50^{\circ} \mathrm{C}$. The reaction products were extracted into diethyl ether, dried under nitrogen and subjected to TLC in hexane/diethylether/acetic acid (70:30:1, v:v:v) to separate fatty acid methyl esters and free fatty alcohols. These were recovered from the plates and the fatty alcohols converted to acetate derivatives by reacting them with acetic anhydride in pyridine (Farquhar 1962). Fatty acid methyl esters and fatty alcohol acetates were identified and quantified by gas-liquid chromatography, by comparison with the internal standard, as detailed by Scott et al. (1999).

Data processing. WE consist of fatty acids and fatty alcohols esterified in equimolar amounts. WE ingested by animals are hydrolysed to free fatty acids and free fatty alcohols which are then assimilated. The free fatty alcohols can then be oxidised to free fatty acids and combined with the assimilated free fatty acids to generate TAG. The assimilated free fatty alcohols can also be re-esterified with the assimilated free fatty acids to regenerate WE (see 'Discussion'). Therefore, to assess the relationship between neutral lipid (WE and TAG) ingested by an animal and neutral lipid deposited in the animal, we have processed weight (wt) \% composi- 
tional data for fatty alcohols and fatty acids in WE in order that fatty acids and fatty alcohols are averaged. This was done by first applying molecular weight values to convert the wt \% data for fatty alcohol acetates, i.e. wt (g) of a given alcohol acetate per $100 \mathrm{~g}$ of total alcohol acetates into mole \% data (i.e. moles of a given alcohol acetate per 100 moles of total alcohol acetates). Such mole \% data for fatty alcohol acetates were then converted to wt $(\mathrm{g})$ of individual alkyl units per mole of total alkyl units. The same calculations were performed on wt \% data for fatty acid methyl esters to give wt (g) of individual acyl units per mole of total acyl units. The sum of the wt ( $g$ ) of individual alkyl units per mole of total alkyl units + the sum of the wt $(\mathrm{g})$ of individual acyl units per mole of total acyl units is then the average molecular wt $(\mathrm{g})$ of the WE in the sample analysed. Wt $(\mathrm{g})$ of individual alkyl units, e.g. 14:0, 16:1n7 and 20:1n-11, per mole were summed with wt (g) of their corresponding acyl units; they then form the calculated average molecular weight of WE, expressed as $100 \mathrm{~g} \mathrm{WE}$ to yield wt (\%) of combined (alkyl + acyl) individual units. Where the sample of total lipid contained TAG as well as WE, data so obtained for WE were combined with the data obtained in the same way for TAG, in proportion to the known \% weights of WE and TAG in total lipid. Such calculations average fatty alcohols and fatty acids in WE and TAG in samples of total lipid. Consequently, compositional data of neutral lipids in predators and prey can be directly compared, irrespective of whether the predator converts either of its dietary neutral lipids (WE and TAG) to the other or it deposits them as such. This is also independent of the extent to which conversions occur.

The foregoing calculations were applied to data for wt \% compositions of fatty acids and fatty alcohols obtained: (1) from Mertensia ovum and Beröe cucumis in the present study; (2) from samples of Calanus finmarchicus, C. glacialis and C. hyperboreus sampled in 1997 at the same time and location as the $M$. ovum and B. cucumis samples were collected (Scott 2000); (3) from Acartia longiremis and Pseudocalanus acuspes, both collected in northern Norway in September 1986 (Norrbin et al. 1990); and (4) from Metridia longa collected in October 1982, again from northern Norway (Falk-Petersen et al. 1987). Of potential ctenophore prey, only these 6 species had been analysed for fatty acid/alcohol composition and thus were available to be tested against the ctenophores. The recalculation was only done for fatty acids and alcohols (14:0, 16:0, 18:1, $22: 1$, etc.) represented with at least 1 value above $0.5 \%$. The reason for not including variables represented with very low amounts in all samples is because the precision of their determination is low and they introduce more noise than real information to the results.
Statistical analyses. Remaining \% values were logtransformed and subjected to principal component analysis (PCA) (Wold 1987) using the program package SIRIUS (Kvalheim \& Karstang 1987).

\section{RESULTS}

The lipid class compositions of Mertensia ovum and Beröe cucumis were very similar (Table 1) with both species containing major amounts of WE $35 \%$ of the total) and minor amounts of TAG (4 to $6 \%$ of the total). Free fatty acids (FFA) (12\% of the total), sterols (4 to $7 \%$ of the total) and partial glycerids (5 to $6 \%$ of the total) were also present. We do not know the source of the FFA, although TAG is likely because of the presence also of partial glycerides. The FFA were not analysed. Phospholipids (PL) were also a major lipid component (35 to $39 \%$ of the total), being somewhat higher in $M$. ovum than in B. cucumis, this was offset by somewhat lower levels of sterols and TAG in $M$. ovum than in B. cucumis.

The dominant fatty acids of the polar lipids (Table 2) were the polyunsaturated fatty acids (PUFA) 22:6n3 and $20: 5 \mathrm{n} 3$ in a ratio of ca $2: 1$, these were somewhat higher in Beröe cucumis than in Mertensia ovum. Polar lipids 16:0, followed by 14:0,18:0 and 18:1n9 were also notable components of both species (Table 2).

TAG is a minor lipid in Beröe cucumis and Mertensia ovum, and sufficient amounts of it were available for analysis only in 1 sample of B. cucumis (Table 3). The mono-unsaturated fatty acids 20:1n9 (24\%) and $22: 1 n 11(20 \%)$ together with $16: 1 n 7(13 \%)$ were the dominant fatty acids in the TAG.

Table 3 shows that the fatty acids of the WE of both Beröe cucumis and Mertensia ovum had notably high levels of $18: 4 \mathrm{n} 3$ (ca $20 \%$ of the total). Essentially the same levels of the saturated fatty acids 14:0 (9\%) and 16:0 (circa 8\%) and the mono-unsaturated fatty acids 18:1n9 (12\%), 20:1n9 (8\%), 22:1n11 (8\%) were present in both species. The fatty alcohols of the WE of both

Table 1. Lipid class compositions in wt $\% \pm \mathrm{SD}$ of Beröe cucumis and Mertensia ovum. Data are means of 3 samples including $4+4+2$ specimens for $B$. cucumis and $8+5+5$ specimens for $M$. ovum. FFA = free fatty acids, TAG = triacylglycerols, WE $=$ wax esters

\begin{tabular}{|lrr|}
\hline Lipid class & Beröe cucumis & Mertensia ovum \\
\hline Polar lipids & $34.9 \pm 7.0$ & $39.0 \pm 2.0$ \\
Partial glycerides & $5.2 \pm 0.2$ & $5.7 \pm 0.7$ \\
Sterols & $7.1 \pm 0.6$ & $4.3 \pm 0.4$ \\
FFA & $12.0 \pm 0.6$ & $11.7 \pm 2.2$ \\
TAG & $5.9 \pm 4.5$ & $4.0 \pm 1.0$ \\
WE & $34.9 \pm 5.4$ & $35.2 \pm 2.4$ \\
\hline
\end{tabular}


Table 2. Fatty acid compositions in wt $\% \pm$ SD of polar lipids of Beröe cucumis and Mertensia ovum. Data are means of the same samples as in Table 1 . SFA = saturated fatty acids, MUFA $=$ monounsaturated fatty acids

\begin{tabular}{|lrr|}
\hline Fatty acid & Beröe cucumis & Mertensia ovum \\
\hline $14: 0$ & $8.5 \pm 1.2$ & $5.4 \pm 0.7$ \\
$16: 0$ & $11.0 \pm 0.2$ & $15.3 \pm 0.9$ \\
$16: 1 \mathrm{n} 7$ & $1.7 \pm 0.3$ & $2.0 \pm 0.4$ \\
$18: 0$ & $6.7 \pm 0.7$ & $6.6 \pm 1.5$ \\
$18: 1 \mathrm{n} 9$ & $5.7 \pm 0.4$ & $4.8 \pm 0.2$ \\
$18: 1 \mathrm{n} 7$ & $1.0 \pm 0.2$ & $0.9 \pm 0.1$ \\
$18: 2 \mathrm{n} 6$ & $0.9 \pm 0.0$ & $0.6 \pm 0.5$ \\
$18: 3 \mathrm{n} 3$ & $1.3 \pm 0.2$ & $0.9 \pm 0.8$ \\
$18: 4 \mathrm{n} 3$ & $2.4 \pm 0.3$ & $4.4 \pm 0.3$ \\
$20: 1 \mathrm{n} 9$ & $1.1 \pm 0.2$ & $1.6 \pm 0.2$ \\
$20: 4 \mathrm{n} 6$ & $0.3 \pm 0.0$ & $0.2 \pm 0.0$ \\
$20: 4 \mathrm{n} 3$ & $1.2 \pm 0.2$ & $1.1 \pm 0.1$ \\
$20: 5 \mathrm{n} 3$ & $16.9 \pm 0.7$ & $14.2 \pm 1.1$ \\
$22: 5 \mathrm{n} 6$ & $0.3 \pm 0.1$ & $0.2 \pm 0.1$ \\
$22: 5 \mathrm{n} 3$ & $0.3 \pm 0.1$ & $0.3 \pm 0.2$ \\
$22: 6 \mathrm{n} 3$ & $30.4 \pm 2.0$ & $27.4 \pm 1.3$ \\
SFA & $27.7 \pm 1.9$ & $29.7 \pm 0.7$ \\
MUFA & $14.7 \pm 0.7$ & $17.6 \pm 2.1$ \\
n6 & $1.9 \pm 0.0$ & $48.2 \pm 2.7$ \\
n3 & $52.5 \pm 1.9$ & \\
\hline
\end{tabular}

species were dominated by $16: 0$, and especially by 20:1n9 and 22:1n11, with no differences between the species. The ratio of $22: 1 \mathrm{n} 11 / 20: 1 \mathrm{n} 9$ was not significantly different and close to unity in both species' fatty alcohols and acids.

The data for wt \% compositions of fatty alcohols and fatty acids in the WE of Metridia longa and Beröe cucumis in Table 3 were processed, as detailed in the 'Materials and methods', to generate an average wt $\%$ composition (Table 4). The same was done for published data of wt \% compositions of fatty alcohols and fatty acids in the WE of Calanus finmarchicus, C. glacialis and C. hyperboreus (Scott 2000), Pseudocalanus acuspes and Acartia longiremis (Norrbin et al. 1990), and M. longa (Falk-Petersen et al. 1987). Of the species considered, only 1 sample of $B$. cucumis and $P$. acuspes had significant levels of both TAG and WE. Therefore, the wt \% fatty acid compositional data for TAG were pooled with wt \% compositional data for WE fatty alcohols and acids to generate the values in Table 4. Except for A. longiremis, which has major amounts of TAG and minor amounts of WE in its neutral lipid, all the other species considered in Table 4 have minor if not negligible levels of TAG in

Table 3. Fatty alcohol and fatty acid compositions (wt \% $\pm \mathrm{SD}$ ) of wax esters (WE) and triacylglycerols (TAG) of Beröe cucumis and Mertensia ovum. For WE, data are means of the same samples as in Table 1. For TAG, data is extracted from 1 sample including 2 specimens of $B$. cucumis. SFA = saturated fatty acids, MUFA = mono-unsaturated fatty acids

\begin{tabular}{|c|c|c|c|c|c|}
\hline & \multicolumn{2}{|c|}{ WE (Beröe cucumis) } & \multicolumn{2}{|c|}{ WE (Mertensia ovum) } & \multirow{2}{*}{$\begin{array}{c}\text { TAG (Beröe cucumis) } \\
\text { Acid }\end{array}$} \\
\hline & Alcohol & Acid & Alcohol & Acid & \\
\hline $14: 0$ & $3.8 \pm 0.9$ & $10.6 \pm 1.3$ & $3.2 \pm 0.6$ & $13.1 \pm 2.8$ & 4.6 \\
\hline $15: 0$ & $0.4 \pm 0.0$ & $0.6 \pm 0.1$ & $0.4 \pm 0.0$ & $0.8 \pm 0.1$ & 0.4 \\
\hline $16: 0$ & $15.3 \pm 1.1$ & $6.8 \pm 0.5$ & $14.4 \pm 0.7$ & $8.2 \pm 0.3$ & 9.4 \\
\hline $16: 1 \mathrm{n} 7$ & $4.0 \pm 0.3$ & $10.0 \pm 1.5$ & $2.5 \pm 0.2$ & $7.4 \pm 0.9$ & 12.5 \\
\hline C16PUFA & $0.0 \pm 0.0$ & $1.0 \pm 0.1$ & $0.0 \pm 0.0$ & $0.7 \pm 0.1$ & 1.4 \\
\hline 18:0 & $0.8 \pm 0.1$ & $0.5 \pm 0.1$ & $0.9 \pm 0.0$ & $0.5 \pm 0.0$ & 1.3 \\
\hline $18: 1 \mathrm{n} 9$ & $5.2 \pm 0.8$ & $12.2 \pm 1.4$ & $5.3 \pm 0.6$ & $11.7 \pm 1.9$ & 5.4 \\
\hline $18: 1 \mathrm{n} 7$ & $1.9 \pm 0.0$ & $0.7 \pm 0.1$ & $1.6 \pm 0.1$ & $0.7 \pm 0.2$ & 2.1 \\
\hline $18: 2 \mathrm{n} 6$ & $1.7 \pm 0.3$ & $1.6 \pm 0.2$ & $1.7 \pm 0.2$ & $1.1 \pm 0.9$ & 0.0 \\
\hline $18: 3 n 6$ & $0.0 \pm 0.0$ & $0.5 \pm 0.1$ & $0.0 \pm 0.0$ & $0.2 \pm 0.2$ & 1.1 \\
\hline $18: 3 n 3$ & $0.0 \pm 0.0$ & $2.0 \pm 0.1$ & $0.0 \pm 0.0$ & $2.2 \pm 0.1$ & 0.5 \\
\hline $18: 4 \mathrm{n} 3$ & $0.0 \pm 0.0$ & $18.7 \pm 0.4$ & $0.0 \pm 0.0$ & $19.3 \pm 1.1$ & 3.4 \\
\hline 20:1n11 & $0.0 \pm 0.0$ & $0.5 \pm 0.1$ & $0.0 \pm 0.0$ & $0.6 \pm 0.1$ & 0.0 \\
\hline $20: 1 n 9$ & $31.6 \pm 1.1$ & $8.5 \pm 1.1$ & $33.0 \pm 0.8$ & $7.8 \pm 1.3$ & 24.1 \\
\hline $20: 4 n 3$ & $0.0 \pm 0.0$ & $1.3 \pm 0.4$ & $0.0 \pm 0.0$ & $1.7 \pm 0.2$ & 0.4 \\
\hline $20: 5 n 3$ & $0.0 \pm 0.0$ & $9.1 \pm 0.7$ & $0.0 \pm 0.0$ & $8.3 \pm 0.1$ & 5.9 \\
\hline $22: 1 n 9$ & $0.0 \pm 0.0$ & $0.0 \pm 0.0$ & $0.0 \pm 0.0$ & $0.2 \pm 0.4$ & 0.0 \\
\hline $22: 1 n 11$ & $31.3 \pm 1.3$ & $7.6 \pm 0.9$ & $32.2 \pm 0.7$ & $7.1 \pm 0.8$ & 20.1 \\
\hline $22: 5 n 3$ & $0.0 \pm 0.0$ & $0.8 \pm 0.1$ & $0.0 \pm 0.0$ & $0.7 \pm 0.0$ & 0.6 \\
\hline $22: 6 n 3$ & $0.0 \pm 0.0$ & $3.1 \pm 0.6$ & $0.0 \pm 0.0$ & $3.4 \pm 0.4$ & 4.4 \\
\hline SFA & $26.5 \pm 4.9$ & $19.1 \pm 1.8$ & $20.5 \pm 0.7$ & $23.4 \pm 2.9$ & 15.7 \\
\hline MUFA & $70.7 \pm 4.3$ & $41.5 \pm 3.4$ & $75.9 \pm 0.4$ & $37.8 \pm 4.9$ & 66.6 \\
\hline n6 & $2.0 \pm 0.2$ & $2.8 \pm 0.5$ & $2.0 \pm 0.3$ & $1.8 \pm 1.1$ & 1.1 \\
\hline n3 & $0.0 \pm 0.0$ & $35.1 \pm 2.3$ & $0.0 \pm 0.0$ & $35.6 \pm 1.0$ & 15.2 \\
\hline $\begin{array}{l}22: \ln 11 / \\
20: 1 n 9\end{array}$ & $1.0 \pm 0.0$ & $0.9 \pm 0.0$ & $1.0 \pm 0.0$ & $0.9 \pm 0.1$ & 0.8 \\
\hline
\end{tabular}


Table 4. Averaged fatty acid and fatty alcohols compositions of neutral lipids in Mertensia ovum and Beröe cucumis and in potential prey organisms. Data are presented as wt \% and are calculated from wt \% compositions of fatty alcohols and fatty acids of wax esters and wt \% compositions of fatty acids in triacylglycerols as detailed in the 'Materials and methods'. The latter data are taken from: for M. ovum and B. cucumis, Table 2; for Calanus finmarchicus (CV and females), C. glacialis (CIV, V and females) and C. hyperboreus (CV and females), Scott et al. (2000); for Pseudocalanus acuspes (CIV and CV) and Acartia longiremis (females), Norrbin et al. (1990); for Metridia longa, Falk-Petersen et al. (1987). (Mo = M. ovum, Bc = B. cucumis, Cf = C. finmarchicus, $\mathrm{Cg}=$ C. glacialis, $\mathrm{Ch}=C$. hyperboreus, $\mathrm{Pa}=P$. acuspes, $\mathrm{Al}=A$. longiremis, $\mathrm{Ml}=\mathrm{M}$. longa $)$

\begin{tabular}{|c|c|c|c|c|c|c|c|c|}
\hline & Mo & $\mathrm{Bc}$ & $\mathrm{Cf}$ & $\mathrm{Cg}$ & $\mathrm{Ch}$ & $\mathrm{Pa}$ & $\mathrm{Al}$ & $\mathrm{Ml}$ \\
\hline $14: 0$ & 7.9 & 6.9 & 5.3 & 4.2 & 3.1 & 15.3 & 13.4 & 23.1 \\
\hline $14: 1 \mathrm{n} 5$ & 0.4 & 0.2 & 0.3 & 0.3 & 0.1 & 0.0 & 0.0 & 0.0 \\
\hline $15: 0$ & 0.6 & 0.5 & 0.5 & 0.5 & 0.2 & 0.7 & 7.2 & 0.0 \\
\hline $16: 0$ & 11.5 & 11.1 & 7.7 & 7.9 & 5.2 & 27.1 & 28.8 & 17.1 \\
\hline $16: 1 \mathrm{n} 7$ & 4.9 & 7.3 & 14.4 & 10.7 & 11.3 & 5.7 & 6.9 & 10.0 \\
\hline $16: 2$ & 0.2 & 0.3 & 1.4 & 0.5 & 0.9 & 0.0 & 0.0 & 1.0 \\
\hline $16: 3$ & 0.2 & 0.3 & 0.7 & 0.5 & 0.7 & 0.0 & 0.0 & 0.0 \\
\hline $16: 4$ & 0.0 & 0.0 & 0.5 & 0.3 & 0.9 & 0.0 & 0.0 & 0.0 \\
\hline $18: 0$ & 0.7 & 0.7 & 0.5 & 1.0 & 0.4 & 1.6 & 6.0 & 0.8 \\
\hline $18: 1 \mathrm{n} 9$ & 8.6 & 8.4 & 2.2 & 3.8 & 1.4 & 29.2 & 16.1 & 24.4 \\
\hline $18: 1 \mathrm{n} 7$ & 1.2 & 1.4 & 2.0 & 1.6 & 1.2 & 1.4 & 1.7 & 2.1 \\
\hline $18: 2 \mathrm{n} 6$ & 1.4 & 1.6 & 0.7 & 0.9 & 0.7 & 1.6 & 1.3 & 2.0 \\
\hline $18: 3 \mathrm{n} 6$ & 0.1 & 0.2 & 0.4 & 0.3 & 0.2 & 0.8 & 1.3 & 0.0 \\
\hline $18: 3 n 3$ & 1.1 & 0.9 & 0.3 & 0.4 & 0.3 & 0.9 & 0.5 & 1.3 \\
\hline $18.4 \mathrm{n} 3$ & 9.4 & 8.7 & 1.3 & 2.9 & 2.9 & 2.5 & 0.0 & 4.9 \\
\hline $20: 0$ & 0.0 & 0.0 & 0.0 & 0.0 & 0.0 & 0.0 & 0.5 & 0.0 \\
\hline 20:1n11 & 0.3 & 0.2 & 0.0 & 0.0 & 0.0 & 0.0 & 0.0 & 0.0 \\
\hline 20:1n9 & 21.6 & 21.2 & 26.1 & 30.5 & 22.9 & 1.2 & 1.2 & 4.1 \\
\hline $20: 1 \mathrm{n} 7$ & 0.4 & 0.1 & 1.7 & 0.9 & 2.7 & 0.4 & 0.8 & 0.0 \\
\hline $20: 4 n 6$ & 0.2 & 0.3 & 0.3 & 0.1 & 0.2 & 0.1 & 0.0 & 0.0 \\
\hline $20: 4 n 3$ & 0.8 & 0.6 & 0.4 & 0.4 & 0.4 & 1.1 & 0.5 & 0.0 \\
\hline $20: 5 n 3$ & 4.1 & 4.6 & 5.5 & 5.9 & 6.1 & 6.7 & 3.7 & 4.0 \\
\hline $22: 0$ & 0.0 & 0.0 & 0.0 & 0.0 & 0.0 & 0.0 & 3.1 & 0.0 \\
\hline $22: 1 \mathrm{n} 11$ & 21.1 & 20.6 & 25.3 & 21.9 & 34.3 & 0.0 & 1.0 & 3.0 \\
\hline $22: 1 \mathrm{n} 9$ & 0.1 & 0.0 & 0.9 & 2.2 & 1.8 & 0.0 & 0.0 & 0.0 \\
\hline $22: 5 n 3$ & 0.4 & 0.4 & 0.3 & 0.4 & 0.5 & 0.0 & 0.0 & 0.0 \\
\hline $22: 6 n 3$ & 1.7 & 1.8 & 0.7 & 1.2 & 1.5 & 3.5 & 1.1 & 2.1 \\
\hline $24: 0$ & 0.7 & 1.1 & 0.4 & 0.0 & 0.1 & 0.0 & 0.0 & 0.0 \\
\hline $24: 1$ & 0.6 & 0.5 & 0.0 & 0.8 & 0.0 & 0.0 & 0.5 & 0.0 \\
\hline
\end{tabular}

their neutral lipid, which is predominantly WE. Therefore, the data in Table 4 are derived from their WE alone.

Inspection of the data in Table 4 reveals that the 3 Calanus species are strikingly similar to Mertensia ovum and Beröe cucumis in having high levels of the long-chain entities 20:1n9 and 22:1n11 in their neutral lipids. The other 3 copepod species are characterised by having high levels of the shorter-chain entities 14:0 and 16:0 in addition to high levels of 18:1n9.

The individual sample values of Mertensia ovum and Beröe cucumis that generated the means in Table 4 were taken together with potential prey and evaluated by principal component analysis (PCA) to generate the 3D principal component (PC) and loading plots presented in Fig. 1. Because of a very low sample:variable ratio $(\mathrm{n}=3$ for each ctenophore species and $\mathrm{n}=1$ for each prey while number of variables = 29), the results must be interpreted cautiously. The first 3 PCs extracted were the only ones with eigen- values $>1$. Hence they were retained. In combination, these 3 components explained $93 \%$ of the variance in the data set. The PC plot (Fig. 1a) shows high similarity between the $M$. ovum and B. cucumis samples and does not distinguish between them. Of the potential prey of $M$. ovum, Calanus glacialis is the most similar to $M$. ovum, closely followed by $C$. finmarchicus and C. hyperboreus (spread along PC 2). Metridia longa and the smaller copepod species Acartia longiremis and Pseudocalanus acuspes have less and little similarity with $M$. ovum (spread along PC 1 and PC 3).

The loading plot demonstrated that 22:1n11, 20:1n9, $18: 1 \mathrm{n} 9,16: 0$ and 14:0 were the most important moieties for distinguishing between samples along PC 1, whereas 18:4n3, 20:1n7, 22:1n9 and 18.1n9 were most important along PC 2 (Fig. 1b). The moieties having the strongest influence on PC 3 are 15:0, 22:0 and 18:0. The moiety $22: 1 \mathrm{n} 11$ varied the most among all samples, with highest representation in Calanus hyperboreus 

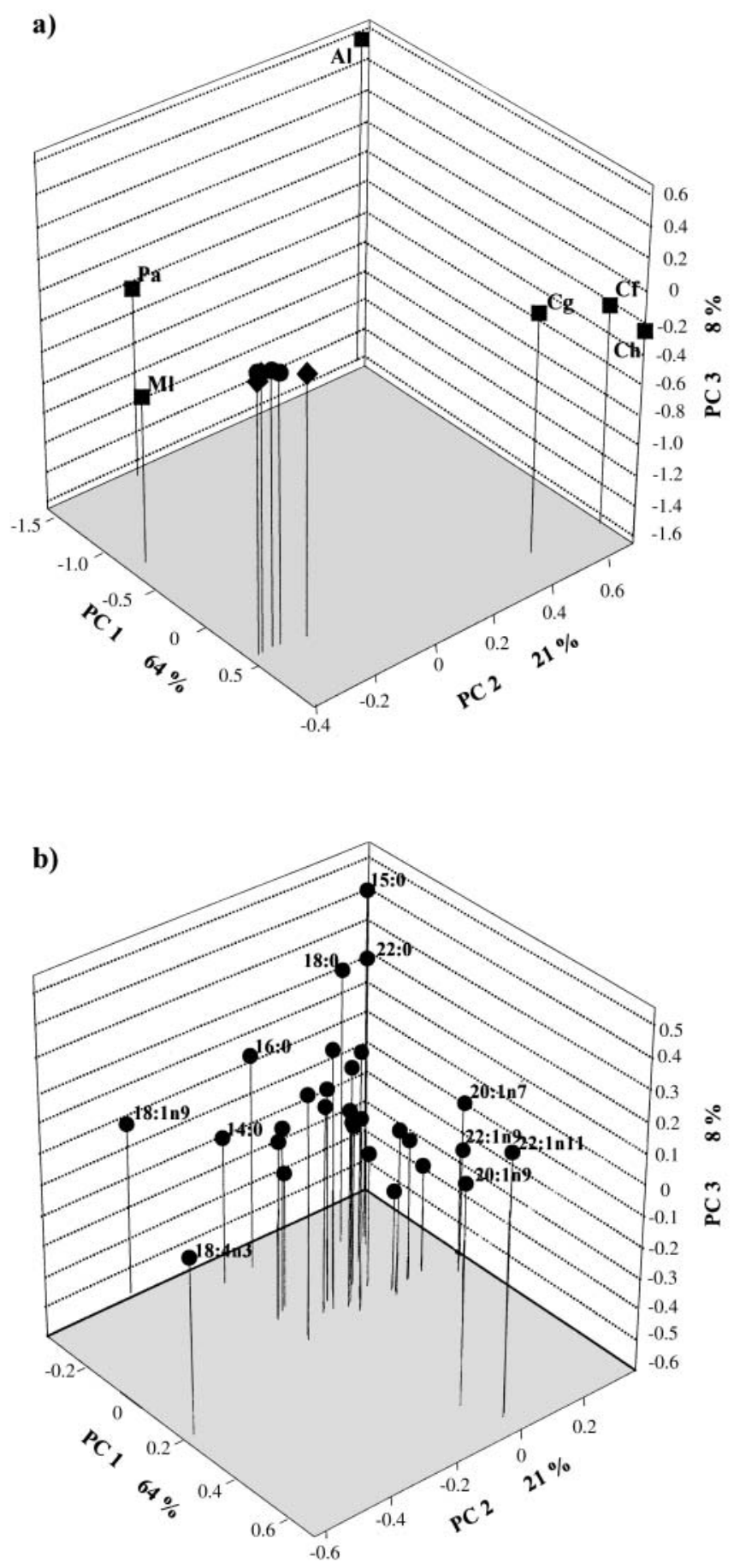

Fig. 1. (a) 3D principal component (PC) plot of Mertensia ovum and Beröe cucumis with potential prey. The analysis is based on the values in Table $4.64 \%$ of the total variance among the samples is explained by PC $1,21 \%$ by PC 2 and $8 \%$ by PC $3 . \bullet=$ Mertensia ovum, = Beröe cucumis. All prey are represented by and the following designations: $\mathrm{Cg}=$ Calanus glacialis, $\mathrm{Cf}=$ Calanus finmarchicus, $\mathrm{Ch}=$ Calanus hyperboreus, $\mathrm{Ml}=$ Metridia longa, $\mathrm{Pa}=$ Pseudocalanus acuspes, $\mathrm{Al}=$ Acartia longiremis. (b) Loading plot of the moieties and their contribution to the spread along PC 1, PC 2 and PC 3. For clarity, only the most important moieties are designated
$(>34 \%)$ and lowest representation in the small copepods $(<1 \%)$.

In an attempt to separate the ctenophores, an additional PCA analysis was run on only these samples (results not shown). Based on the extraction of a significant amount of components (eigenvalue $>1$ ), the analysis did not separate the 2 ctenophore species. This amplifies the degree of similarity in moiety composition among these species.

\section{DISCUSSION}

In assessing potential animal prey for Beröe cucumis and Mertensia ovum on the basis of fatty acid profiles of their lipids, we have considered only neutral lipids in this study. This is because the fatty acid profiles of animal phospholipids tend to be conserved and relatively independent of dietary input, whereas the profiles of neutral lipids are much more variable and more readily influenced by dietary input (Sargent \& Henderson 1995). The polar lipids (predominantly phospholipids) of B. cucumis and M. ovum are characteristically rich in the long-chain n-3PUFA 20:5n3 and 22:6n3, as is true of marine animals in general, reflecting their basic roles in cell membrane structure and function. The preponderance of 22:6n3 over 20:5n3 found here for the polar lipids of B. cucumis and M. ovum occurs also in the polar lipids of Calanus finmarchicus, $C$. glacialis and C. hyperboreus (Scott 2000).

In considering neutral lipids as indicators of predator-prey relationships, a complication is that animals preying on WE-rich prey can either convert their dietary lipids to TAG, as occurs, e.g. in Meganyctiphanes norvegica (Sargent \& Falk-Petersen 1981), or deposit dietary WE as such, as occurs, e.g. in Euchaeta norvegica (Sargent \& Henderson 1986). Therefore, in this study we have averaged given fatty alkyl and fatty acyl units of WE, i.e. units with the same chain lengths, and numbers and positions of double bonds, so treating WE and TAG as one and the same. The compositional data (Table 4) can then be related to neutral lipid in a predator consuming WE, irrespective of whether the predator converts its dietary WE to TAG or deposits them directly as WE.

The 20:1n9 and 22:1n11 units present in very large amounts in calanoid copepods are considered to be formed by de novo biosynthesis from phytoplanktonic precursors. In our present understanding, calanoid copepods are the major if not the only site of the formation of 20:1n9 and 22:1n11 units in the marine food web (Sargent \& Henderson 1986). The data shown here (Table 4) for Calanus finmarchicus, C. glacialis and C. hyperboreus from Svalbard waters show very clearly the abundance of 20:1n9 and 22:1n11 units in the lipids 
of these species, with C. hyperboreus having the highest level of 22:1n11. Moreover, 20:1n9 and 22:1n11 are also abundant in Mertensia ovum and Beröe cucumis (Table 4), as these species have essentially an identical lipid class composition with WE predominating (Table 1). The obvious similarity between the 3 Calanus spp. and $M$. ovum and B. cucumis in Table 4 is confirmed in the PCA analyses, with the 5 species having similar scores on PC 1 and PC 3 (Fig. 1a). In contrast, there are few similarities between Metridia longa, Pseudocalanus acuspes and Acartia longiremis, either by inspection of the analytical data in Table 4 or by PCA (Fig. 1a). M. longa and the small copepod species are quite different from each other, and from the 3 large Calanus copepod species and from $M$. ovum and B. cucumis. Thus, the data here are entirely consistent with strong predatorprey relationships between the ctenophores and the large Calanus copepods, but not between the ctenophores and the smaller copepods. Unfortunately, we cannot exclude the implication of different years of sampling on moiety composition. Nevertheless, we believe our results are quite robust as we have experienced small year-to-year variations in the moieties (22:1n11, 20:1n9, 18:4n3, 18:1n9, 15:0 and 14:0) most important for the separation of samples.

The fatty acid/alcohol profiles of Mertensia ovum, Beröe cucumis and the 3 Calanus spp. found here appear to be in accordance with what is well known in the literature, confirming the usefulness of lipid profiles in studying predator-prey relationships. More specifically, the analytical data here supported by PCA classifies M. ovum as being more similar to Calanus glacialis than either C. finmarchicus or C. hyperboreus. Siferd \& Conover (1992) found that M. ovum mainly preyed on C. glacialis, C. hyperboreus, Pseudocalanus acuspes and Parathemisto libellula. Our study, however, rules out small copepods such as $P$. acuspes and Acartia longiremis being an important part of the diet of M. ovum in terms of energy intake. Scott and colleagues (Scott 2000, unpubl. data) showed that $C$. hyperboreus is the most energy-rich of the 3 calanoid copepods here, followed by C. glacialis and C. finmarchicus. However, C. hyperboreus is not an important species in Kongsfjord in terms of numbers and biomass as compared to the very abundant $C$. finmarchicus and C. glacialis. Therefore, taking into account both the abundance and the energy content of the 3 Calanus species, C. glacialis is likely the preferred prey for M. ovum in Kongsfjord.

The conservative transfer of fatty acids into neutral lipids in higher trophic levels has been demonstrated by Falk-Petersen et al. $(1987,1990)$. Of the important phytoplankton in polar waters, the diatoms tend to be rich in 20:5n3, 16:1n7 and C16 PUFA but deficient in C18 PUFA. The dinoflagellates tend to be rich in
$18: 4 n 3,18: 5 n 3$ and especially $22: 6 n 3$, but deficient in 16:1n7. Phaeocystis pouchetii, a species that often dominates the blooms in polar waters, tend to be characterised by this pattern (Sargent et al. 1985, Hamm et al. 2001). The synthesised data in Table 4 indicate that diatoms were the dominating food source of Calanus spp. in 1997, and that dinoflagellates and P. pouchetii could not have been an important part of the diet. Although Mertensia ovum is an opportunistic feeder (Swanberg \& Båmstedt 1991, Siferd \& Conover 1992), we can conclude from our analysis that Calanus spp. are the major energy source for this ctenophore as well as for Beröe cucumis. This emphasises the key role of Calanus spp. within Arctic food chains.

The current results based on lipid biochemistry and multivariate statistical methods provide additional supporting evidence that: (1) the 3 Calanus species are the main herbivores in the area studied, feeding mainly on diatoms; (2) Calanus spp. are the prime species for Martensia ovum; and (3) Beröe cucumis feeds heavily on $M$. ovum.

Calanus species are herbivorous, converting principally carbon which has been fixed in diatoms during the Arctic primary production bloom to large reserves of energy-rich WE. The fact that high levels of WE can be transmitted, with minimal change in their fatty acid and fatty alcohol compositions, to Martensia ovum and hence to Beröe cucumis emphasises the ease and efficiency of energy transmission through the Arctic ecosystem.

\section{LITERATURE CITED}

Boldovsky BG (1944) The food of the Norway haddock in the Barents Sea. Tr Polyarn Nauchno-Issled Proektn Inst Morsk Rybn Khoz Okeanogr 8:307-330 (in Russian)

Brown DJ, Boyd IL, Cripps GC, Butler PJ (1999) Fatty acid signature analysis from the milk of Antarctic fur seals and Southern elephant seals from South Georgia: implications for diet determination. Mar Ecol Prog Ser 187:251-263

Clarke A, Holmes LJ, Hopkins CCE (1987) Lipid in an Arctic food chain: Calanus, Bolinopsis, Beroe. Sarsia 72:41-48

Dahl TM, Lydersen C, Kovacs KM, Falk-Petersen S, Sargent JR, Gjertz I, Gulliksen B (2000) Fatty acid composition of the blubber in white whales (Delphinapterus laucas). Polar Biol 23:401-409

Falkenhaug T (1996) Distributional and seasonal patterns of ctenophores in Malangen, northern Norway. Mar Ecol Prog Ser 140:59-70

Falk-Petersen S, Sargent JR, Tande K (1987) Lipid composition of zooplankton in relation to the sub-Arctic food web. Polar Biol 8:115-120

Falk-Petersen S, Hopkins CCE, Sargent JR (1990) Trophic relationships in the pelagic arctic food web. In: Barnes M, Gibson RN (eds) Trophic relationships in the marine environment. Aberdeen Univ Press, Aberdeen, p 315-333

Falk-Petersen S, Hagen W, Kattner G, Clarke A, Sargent JR (2000a) Lipids, trophic relationships and biodiversity in Arctic and Antarctic krill. Can J Fish Aquat Sci 57:178-191 
Falk-Petersen S, Hop H, Budgell WP, Hegseth EN, Korsnes R, Løyning TB, Ørbæk JB, Kawamura T, Shirasawa K (2000b) Physical and ecological processes in the marginal ice zone of the northern Barents Sea during the summer melt periods. J Mar Syst 27:131-159

Farquhar JW (1962) Identification and gas-liquid chromatographic behavior of plasmalogen aldehydes and their acetal, alcohol, and acetylated alcohol derivatives. J Lipid Res 3:21-30

Folch JM, Lees M, Sloane GH (1957) A simple method for the isolation and purification of total lipid from animal tissues. J Biol Chem 226:497-509

Grahl-Nielsen O, Mjaavatten O (1991) Dietary influence on fatty acid composition of blubber fat of seals as determined by biopsy: A multivariate approach. Mar Biol 110: 59-64

Grahl-Nielsen O, Mjaavatten O (1995) Marine mammalian fatty acids: a source of information. In: Blix AS, Wallø L, Ulltang $O$ (eds) Whales, seals, fish and man. Elsevier Science Publishers, Amsterdam, p 141-152

Hamm CE, Reigstad M, Wexels-Riser C, Mülebach A, Wassmann P (2001) On the trophic fate of Phaeocystis pouchetii: VII. Sterols and fatty acids reveal sedimentation of Phaeocystis-derived organic matter via krill fecal strings. Mar Ecol Prog Ser 209:55-69

Hansen PM (1949) Studies on the biology of the cod in Greenland waters. Rapp P-V Reun Cons Int Explor Mer 123:1-77

Harbison GR, Madin LP, Swanberg NR (1978) On the natural history and distribution of oceanic ctenophores. Deep-Sea Res 25:233-256

Hoeger U, Mommssen TP (1984) Hydrolytic enzymes in the two North Sea ctenophores Pleurobrachia pileus and Beroe glacilis. Mar Biol 81:123-130

Iverson SJ, Arnould JPY, Boyd IL (1997a) Milk fatty acid signatures indicate both major and minor shifts in the diet of lactating Antarctic fur seals. Can J Zool 75:188-197

Iverson SJ, Frost KJ, Lowry LF (1997b) Fatty acid signatures reveal fine scale structure of foraging distribution of harbor seals and their prey in Prince William Sound, Alaska. Mar Ecol Prog Ser 151:255-271

Kamishlov MM (1960) Feeding of ctenophore Beroe cucumis. Dokl Akad Nauk SSSR 130:1138-1140

Kamishlov MM, Zelikman EA, Roukhivainen MI (1958) Plankton of the coastal zone of the Murman. In: Natural phenomenon in aggregations and migrations of fish in the coastal zone of the Murman and its relation with biological, hydrological and hydrochemical processes. Akademie Nauk SSR, Moscow, p 59-102 (in Russian)

Kirsch PE, Iverson SJ, Bowen WD, Kerr SP, Ackman RG (1998) Dietary effects on the fatty acid signature of whole Atlantic cod (Gadus morhua). Can J Fish Aquat Sci 55: 1378-1386

Kirsch PE, Iverson SJ, Bowen WD (2000) Effect of a low-fat diet on body composition and blubber fatty acids of captive juvenile harp seals (Phoca groenlandica). Physiol Biochem Zool 73:45-59

Kvalheim OM, Kvarstang TV (1987) A general-purpose program for multivariate data analysis. Chem Intell Lab Syst 2:235-237

Norrbin MF, Olsen RE, Tande KS (1990) Seasonal variation in lipid class and fatty acid composition of two small copepods in Balsfjorden, northern Norway. Mar Biol 105: 205-211

Olsen RE, Henderson J (1989) The rapid analysis of neutral

Editorial responsibility: Otto Kinne (Editor),

Oldendorf/Luhe, Germany and polar marine lipids using double-development HPTLC and scanning densitometry. J Exp Mar Biol Ecol 129:189-197

Raclot T, Groscolas R, Cherel Y (1998) Fatty acid evidence for the importance of myctophid fishes in the diet of king penguins, Aptenodytes patagonicus. Mar Biol 132:523-533

Sargent JR, Falk-Petersen S (1981) Ecological investigations on the zooplankton community of Balsfjorden, northern Norway: lipids and fatty acids in Meganyctiphanes norvegica, Thysanoessa raschii and T. inermis during midwinter. Mar Biol 62:131-137

Sargent JR, Henderson RJ (1986) Lipids. In: Corner EDS, O'Hara SCM (eds) The biological chemistry of marine copepods. Clarendon Press, Oxford, p 59-164

Sargent JR, Henderson RJ (1995) Marine (n-3) polyunsaturated fatty acids. In: Hamilton RJ (ed) Developments in oils and fats. Blackie Academic and Professional, London, p 32-65

Sargent JR, Whittle K (1981) Lipids and hydrocarbons in the marine food web. In: Longhurst A (ed) Analysis of marine ecosystems. Academic Press, London, p 491-533

Sargent JR, Eilertsen HC, Falk-Petersen S, Taasen JP (1985) Carbon assimilation and lipid production in phytoplankton in northern Norwegian fjords. Mar Biol 85:109-116

Scott CL (2000) Calanoid copepods and ice fauna in arctic fjords and regions of the marginal ice zone around Svalbard: Lipids; stage distributions; trophic interactions; trophic interactions and life strategy. PhD thesis, University of Stirling, p 202

Scott CL, Falk-Petersen S, Sargent JR, Hop H, Lønne OJ, Poltermann M (1999) Lipids and trophic interactions of ice fauna and pelagic zooplankton in the marginal ice zone of the Barents Sea. Polar Biol 21:65-70

Scott CL, Kwasniewski S, Falk-Petersen S, Millar RM, Sargent JR (2000) Life strategy of arctic copepods: stage distribution and lipids of Calanus finmarchicus, Calanus glacialis and Calanus hyperboreus in late autumn, Kongsfjord, Svalbard. Polar Biol 23:510-516

Siferd TD, Conover RJ (1992) Natural history of ctenophores in the Resolute Passage area of the Canadian High Arctic with special reference to Mertensia ovum. Mar Ecol Prog Ser 86:133-144

Smith SJ, Iverson SJ, Bowen WD (1997) Fatty acid signatures and classification trees: New tools for investigating the foraging ecology of seals. Can J Fish Aquat Sci 54:1377-1386

Swanberg N (1974) The feeding behavior of Beroe ovata. Mar Biol 68:69-76

Swanberg N, Båmstedt U (1991) Ctenophora in the Arctic: the abundance, distribution and predatory impact of the cydippid ctenophore Mertensia ovum (Fabricius) in the Barents Sea. Polar Res 10:507-524

Tamm S, Tamm SL (1991) Reversible epithelial adhesion closes the mouth of Beroe, a carnivorous marine jelly. Biol Bull 181:463-473

Walton MJ, Henderson RJ, Pomeroy PP (2000) Use of blubber fatty acid profiles to distinguish dietary differences between grey seals Halichoerus grypes from two UK breeding colonies. Mar Ecol Prog Ser 193:201-208

Wold S (1987) Principal component analysis. Chem Intell Lab Syst 2:37-52

Zelikman EA (1972) Distribution and ecology of the pelagic hydromedusae, siphonophores and ctenophores of the Barents Sea, based on perennial plankton collections. Mar Biol 17:256-264

Submitted: February 13, 2001; Accepted: August 27, 2001

Proofs received from author(s): February 4, 2002 